\title{
Performance of Affects and Imitation of Emotions: A Study on Babis Makridis's Pity Film
}

\author{
Filiz Erdoğan Tuğran*
}

\begin{abstract}
According to Gabriel De Tarde, from the moment a person is born, she/he creates her own behavior by imitating those around her/his. Tarde, in his book "Laws of Imitation", which was published in a new edition in 1903; He mentions the importance of imitation and invention by saying "Everything socially is an invention or imitation, the relationship between the two is like the relationship between mountain and river"(Tarde, 1890 [1993], p. 3). Moreover, in the same work, he once again mentions the social importance of imitation by saying "In order for an invention to be considered an invention, it must be imitable". Therefore, while creating human identity, which is a social being, it creates itself by feeding on the environment, people around it, literature and art. With the invention of cinema, this situation continues intensely by noticing the characteristics of movie characters and trying to resemble them. This process of imitation is also effective in the formation of the behaviors and therefore the emotions that come out with them. As the human being is also affected by the culture and historical processes she/he is in, she/he tries to create her/his own individuality within differences and samenesses. The article will discuss the performance and imitations of emotions based on Babis Makridis' film Oiktos (Zavall, Babis Makridis, 2018), which has been in the current called 'Greek Strange Wave' in recent years, and will try to examine the film through Brauch Spinoza's concepts of affect and question the possibility of Ulus Baker's proposal for a sociology of emotions.. The questions of how human emotions are formed and how emotional behaviors are shaped will be asked through the anonymous main hero of the film and answers will be sought.
\end{abstract}

Key Words: Greek Weird Wave, Sociology of Emotions, Cinema, Gabriel de Tarde, Ulus Baker, Baruch Spinoza

\footnotetext{
*Ondokuz Mayıs University, Faculty of Communication, Samsun, Turkey

E-mail: filizerdogant@gmail.com

ORCID : 0000-0002-2793-0289

DOI: $10.31122 /$ sinefilozofi.889367

Erdoğan Turan, F. (2021). Performance of Affects and Imitation of Emotions: A Study on Babis Makridis's Pity Film. Sinefilozofi Dergisi, Özel Sayı (3), 442-454. https// doi.org//10.31122/sinefilozofi.889367
}

Recieved: 02.03.2021

Accepted: 23.08.2021 


\title{
Performans Olarak Duygulanım ve Duyguların Taklidi: Babis Makridis'in Zavallı Filmi Üzerine Bir İnceleme
}

\author{
Filiz Erdoğan Tuğran*
}

\section{Özet}

Gabriel Tarde'a göre insan doğduğu andan itibaren çeoresindekileri taklit ederek kendi davranışların oluşturur. Tarde, 1903 yılında yeni bir edisyonuyla tekrar yayımlanan 'Taklidin Yasaları' adlı kitabında; 'Toplumsal olarak her şey icat ya da taklittir, ikisinin birbiri ile olan ilişkisi ise dağ ve nehir arasındaki ilişki gibidir' (Tarde, 1890 [1993], p. 3) diyerek taklit ve icadın öneminden bahseder. Hatta yine aynı eserde 'bir buluşun icat sayılabilmesi için onun taklit edilebilir olması zorunluluktur' diyerek taklidin toplumsal önemine bir kez daha değinir. Dolayısıyla toplumsal bir varlik olan insan kimliğini oluştururken çevresinden, etrafindaki insanlardan, edebiyat ve sanattan da beslenerek kendini var eder. Bu durum sinemanın icadiyla birlikte film karakterlerinin de özelliklerini fark etmek, onlara benzemeye çalışmak üzerinden yoğunlukla devam eder. Bu taklit süreci davranışların ve dolayısıyla onlarla birlikte açığa çıkan duygularn oluşmasında da etkili olur, insan, içinde bulunduğu kültürden, tarihsel süreçlerden de etkilendiği için farklılıklar ve aynılıklar içerisinde kendi bireyselliğini oluşturma çabası içindedir. Makale, son yıllarda 'Yunan Tuhaf Dalgası' olarak da adlandırılan akım içerisinde bulunan, Babis Makridis'in 2018 yılında yönettiği Oiktos (Zavall, Babis Makridis, 2018) filminden hareketle duyguların performansı ve taklit edilmesi bağlamında tartışmalar yapacak, Brauch Spinoza'nın duygulanım kavramlar üzerinden filmi inceleyecek ve Ulus Bakerin duygular sosyolojisi önerisinin imkanını sorgulayacaktır. İnsanın duyguları nasıl oluşur, duygusal davranışlar nelere göre şekillenir soruları filmin adsız ana kahramanı üzerinden sorulacak ve bu sorulara yanıt aranacaktır.

Anahtar Kelimeler: Yunan Tuhaf Dalgası, Duygular Sosyolojisi, Sinema, Gabriel de Tarde, Ulus Baker, Baruch Spinoza

\footnotetext{
*Ondokuz Mayıs Üniversitesi, İletişim Fakültesi, Samsun, Türkiye

E-mail: filizerdogant@gmail.com

ORCID :0000-0002-2793-0289
}

DOI:10.31122/sinefilozofi.889367

Erdoğan Turan, F. (2021). Performance of Affects and Imitation of Emotions: A Study on Babis Makridis's Pity Film. Sinefilozofi Dergisi, Özel Sayı (3), 442-454. https//doi.org//10.31122/sinefilozofi.889367

Geliş Tarihi: 02.03.2021

Kabul Tarihi :23.08.2021 


\section{Introduction}

The history of thought of the Western world is always constructed on a dual structure. Dualities such as god, man, mind, body, human, animal are common discourses encountered in the texts of many thinkers. Undoubtedly, the most striking aspect of these conventional discourses is that the dualities are hierarchically lined up and one of them is definitely above the other. With Enlightenment thought and modernity, mind came to the top of this hierarchy and since the mind is also the human mind, everything else is hierarchically below the human condition. The philosophical method of Descartes lies in this point. After giving this indubitable knowledge about the existence of the self, he started searching for other aspects like bodily knowledge, external world and so on. The basic aspect of Cartesian philosophy is the dualism between Body and Mind (Bansidhar: 2014, p. 30). According to this system of thought, being an animal is less valuable than being a human for example, in the rationality that glorifies the mind, the mind-body distinction is made essential and the body is positioned in the secondary place, just below the mind. Especially Jacques Derrida, Gilles Deleuze and Baruch Spinoza opposed this binary opposing thought system and tried to displace this dualism and shake its roots.

According to Derrida; all dualisms, theories of the immortality of the whole soul or spirit, as well as spirituality or all monisms, whether materialistic, dialectical or otherwise, are probably the unique theme of a metaphysics that is directed towards the reduction of the whole historical trace. (Derrida, 2014, p. 109). In other words, Modernity was trying to throw metaphysical thought into the background with this kind of binary thought system; however, by placing one of these dualities hierarchically above the other, it actually fell into exactly metaphysical thought. "Thus, Derrida deconstructs the idea of Logos-centrism by saying that this Cartesian philosophy that excludes metaphysics is actually itself based on a metaphysical basis. One of such notions is mentioned duality, which is also the criterion in the creation of such oppositions like inside and outside, distinctions like mind and body or thing and its appearance (Klos, 2014, p. 95)".

Logocentric system of thought always found a concept to establish superiority, for example the word always stood above the writing. "Logocentrism, for Derrida, is based on a profound misunderstanding of the relation between signifier and signified, namely the belief that a sign adequately represents its signified meaning, that language is a transparent window on reality. Such a view automatically privileges speech over writing, and full presence over absence (Moran, 2000, p. 448)". Poststructuralists displace this dual structure, helping the body and mind become equally important, because for them one cannot work without the other. This situation is discussed based on Spinoza's speech on mind, body and affects.

Spinoza, stated that the body thrown into the background for the sake of these dualities is not only the body, but because the emotions will emerge through bodily encounters, the affects are also thrown into the secondary place. Feelings had no place in modern thought, Even though Romantic thought betrayed the age of reason that started since the Enlightenment by bringing the emotions and the subject to the fore, rationality suggested to look at the whole world objectively, that is, without involving emotions.

Since the establishment of sociology as a science, sociologists have begun to examine societies from a positivist perspective. Modernity, which ascribes a pejorative meaning to everything about metaphysics, thinks of sociological thinking just like physics, chemistry, or biology, and envisions the study of societies at a distance between a scientific object and a scientist. However, as the science of sociology was systematized, it was not easy to understand societies. Progressive understanding of science or deterministic social inferences did not reflect the truth. The progressive approach that had been discredited by World War II led to the loss of faith in meta narratives. This loss of belief, whose theoretical foundations were laid with poststructuralist thinking, began to look for answers to some questions in different places. 
While sociologists such as Gabriel de Tarde, whose thoughts were ignored in his period, were re-read, poststructuralist thinkers tried to destroy the dualistic structure by re-reading philosophers such as Immanuel Kant and Friedrich Hegel. On the other hand, Ulus Baker talked about a sociology of emotions based on Spinoza in his doctoral thesis where he made suggestions for the 21st century. Drawing on Spinoza's concept of affect, Baker will discuss whether a sociology of emotions is possible. Throughout the film, concepts such as the feeling of mourning in the footsteps of the main character and asking for self-pity will be considered and the main character's attempt to live by imitating the emotions will be evaluated and based on Gabriel Tarde's concept of imitation, the question will be asked whether we can reach the idea Spinoza calls affect. With these thoughts, when the main character in the film Pity, directed by Babis Makridis in 2018, is examined, the emotional deficiency felt by the body, which is constantly closed to encounters, and the effort to complete this deficiency are tried to be understood.

\section{Sociology of Emotions or Being Open to Affections}

In Ethica, Spinoza talks about the state of opening the body to affects and says that the body is a place of encounters. According to his thoughts we must eliminate the duality of Mind and Body because if bodily encounters do not occur, it is not possible to obtain mental projections of these encounters. Therefore, separating the mind and body, going even further to isolate one by placing one above the other causes the body, which is the place of experiences and encounters, to become insignificant however it is out of the question to feel emotions without a body. However, according to Spinoza, all we have is the idea of the body's affections. "So there is a relationship of reciprocity between the affects of the body and the ideas of the mind, these affections represent these ideas in this way." (Deleuze, 2005, p. 114).

At this point, Sara Ahmed talks about the body as a host of encounter and focuses on the feeling of pain. "Let's say I accidentally hit my toe against the table. The effect of the table is a kind of negation; It leaves its mark on my skin and I respond with an appropriate "uflff" and walk away by cursing (Ahmed, 2014, p. 38)". In other words, pain is what is felt in the mind as a result of the body encountering an external object, but if there is no encounter, one will never know the feeling of pain.For example, a child who does not touch a hot pan will not know that it is going to burn her/his hand, but once experienced, she/he will avoid touching the pan again. "In this example, I "feel" the surface painfully, moving my foot away from the surface of the table, which I see as the cause of my pain. I move away from what I feel as the cause of my pain; it feels like I'm walking away from the pain (Ahmed, 2014, p. 38)". That is, in order to experience emotions mentally once, bodies must open up to encounters.

Spinoza, on the other hand, talks about the concept of conatus and, as positive emotions will create enthusiastic desires, he talks about opening the body to encounters as the sphere of joyful emotions but he does that without keeping the body separate from the mind.

The ability to affect is necessarily filled in in any case, as it should be according to the given affect (ideas of objects encountered). Even illness is such a stuffing. But the big difference between the two situations is that in the case of grief, our power as the conatus is wholly to surround the painful scar and to remove or destroy the object that caused it. Our strength is frozen and cannot do anything but react. In a state of joy, on the contrary, our might increases. It combines with the power of the other and merges with the loved object (Spinoza, 2011, p. 18).

Ulus Baker proposes the sociology of emotions in his book From Opinions to Images and wants social types to gain importance again. He suggests that these types should be reexperienced by imitation and opening the body to encounters, and that social unification can be paved by common affections. "Our argument for the feasibility of the Sociology of Emotions is that the creation of social types and social landscapes is essential for any effort to regenerate sociology" (Baker, 2012, p. 25). 
Since individuals who can not open their bodies to encounters cannot feel common emotions, the way to sociability is blocked and the areas that can be viewed with a sociological perspective are blurred.

\section{Affect or a Strange Mourning in Pity Movie}

A reproduction of the discourse mostly provided by film critics in leading journals and newspapers like Cahiers du Cinema and The Guardian about the so called 'Greek Weird Wave' (Nikolaidou, 2014: 21) or in other words Greek New Wave's roots go back to the years when Greek cinema started to gain attention worldwide. Cinema critics had a hard time naming this movement, caught between the name Greek Bizarre Wave or the Greek New Wave. The reason for this can be seen as the silence of the directors involved in the movement and the really strange patterns of the movement. Changes and innovations in Greek Cinema have caused the world to look there. This attention was first brought about by the movie Reconstruction directed by Theo Angelopoulos in 1970. Later, many films shot by the same director attract the attention of cinema critics, and Greek Cinema creates a different language and different images and becomes familiar with the attention of cinema lovers all over the world. After his great success with the movie Eternity and a Day, he has received awards from many festivals and contributes significantly to the development of the cinema industry in Greece. When it comes to 2009, this time a shocking movie emerges, while the Dogtooth film by Yorgos Lantimos returns with plenty of awards from the festivals, eyes turn to Greek Cinema once again however, this time the situation is a little different because Greek Cinema takes on a mission that destroys and disrupts the existing imaginary integrity instead of creating a new language. Lantimos invites the audiences to rethink everything they know while attacking the family institution and language element with his sharp imagination. Lantimos and his team, who made quite new films after this movie that made great success, are laying the foundations of a new trend that will be described as the Greek Weird Wave all over the world. Joachim Lepastier, in a comment on Psykou's film in Cahiers du Cinema, writes of "une manière grecque", "a Greek way", which is characterized by a "reclusion in a post-modern décor", "arrhythmic narration", "warped humor", "weirdness but perhaps too calculated" (Lepastier, 2013, p. 66 - Trans. Nikolaidou, 2014, p. 22). This cynical attitude is clearly observed in almost all films of the movement, and it is absurd that the characters do not have problems with money despite the economic crisis. Without doubt, the financial crisis has defined the context of production, exhibition, and reception of the Greek New Wave cinema, a cinema that originates from a country determined by fragile economic conditions that have accordingly led to transformations in the domestic cinematic landscape (e.g., Anderson 2013; Chalkou 2012- Trans. Basea, 2016, p. 63).

The Greek Weird Wave contains patterns in which the critics overlap at certain points, at the top of which is the sense of in-betweenness that the characters experience. "Put simply, the Greek new wave cinema rests in between the knowable and the unknown, a critique of crisis capitalism and weirdness. This in- betweenness of contemporary Greek cinematic images is powerful exactly because it gives them the potential to become a site of interrogation of what the crisis is" (Basea, 2016, p.64).

These films, initially shot with very low budgets and bearing the signature of a certain team, gradually become the most interesting spectacles of the festivals. The movie mentioned in the article is Pity, which was shot in 2018 by Babis Makridis and Efthymis Filippou (he accompanied Lanthimos as scriptwriters in many of his films).

The film begins with the shutters open, as if the director is opening the doors to a bright world for the audience. However, the main character, whose name we have never learned, has almost no connection with the modern Greek city illuminated by this daylight. The hero has isolated his body from the outside world, eliminating the possibilities of any encounter in his mind. He lives with his son, as the movie progresses, it is learned that the 
man's wife is in a hospital and is in a coma, so his neighbor feels sorry for him and brings him a cake in the morning and every morning just before his neighbor arrives, he is seen waiting outside the door for the cake she will bring. It is not seen that he communicates with anyone except his neighbor, the secretary working with him, his clients, the nurse who takes care of his wife in the hospital, the dry cleaner, his father, and his friend Nikos, who is the only character encountered in the film and whose name is declared. Their communication with these characters is usually one-sided and the conversations are based on the situation of his wife in a coma. He will have a very limited dialogue with his son and his wife, who later came out of a coma. Throughout the film, Wolfgang Amadeus Mozart's Requiem accompanies the main character. This composition, which was the last order Mozart received before his death, was composed for the death of his client's wife, but Mozart passed away before he could finish this composition ${ }^{1}$.

The main character seems to wake up to the same sunny day every morning, rehearse crying, take the cake given by his neighbor with monotony movements, have breakfast with his son in silence, go to work and tell his secretary about his concern for his wife. The first part of the film proceeds with sequences in which the main character tells about how sorry he is for his wife, to the people I have just mentioned, and occasionally visits his wife at the hospital. These sequences are very subtle, each time he visits the hospital, he puts his wife's hands on her chest and says goodbye with a kiss on her lips. When he leaves the hospital, his life, which he continues with mechanical movements, seems colorless and even silent, except for the conversations he opened from his wife. Especially to his friend Nikos, he often tells about his longing for his wife and how lonely he is, and he complains that he cannot even wear sunscreen while swimming at the beach. He did not respond to Nikos's proposal as "I can apply in a place that nobody has seen, if you want" and it was observed that he did not want to open his body to this encounter.

The second part of the film begins with his wife suddenly awakening from a coma, his wife had a traffic accident and remained in a coma for an indefinite period of time, while the audience thought that this awakening would have positive effects on the main character, the protagonist was unresponsive to his wife's awakening, even in the later parts of the film he was uneasy about this incident. He lies to the dry cleaner that his wife is still in a coma, and continues to go to the hospital, making up stories about his wife's illness to the patient attendants he meets there. In one scene, he enters the room of a patient in a coma and says goodbye to him in the same way he did to his wife, clasps his hands on his chest, leaves the room with a kiss on his lips. This ritual of farewell is an irresistible act for the man, a form of farewell to another body. This ritual, which he created by imitating a mourning tradition, makes him think that he can only open his body to encounters with bodies in vegetative life. After all this ceremony, he goes home as if he is returning from work, and family relations are revealed, where the lack of communication is clearly at the center.

Throughout the film, the protagonist's relationship with his wife is rather shallow, when his wife wants to be with him, he refuses and warns her of the danger of breast cancer and says that she should have a mammogram. The hero, who is successful in his job, lives in a luxury house with sea view, gets on an expensive car, lives a peaceful life with his wife, child and dog Cookie, seems to be dragged in an expressionless face and an uneasy mood under all these positive conditions. Many frames of the film are shot from outside the buildings where the protagonist is located, and the director is framing the film from inside and outside, as if the protagonist stands somewhere between the interior and the exterior, but does not touch either side. He does not look carefully at almost anything around him, the things he looks carefully at is the cry of his client who lost his father and the painting of a calm sea view that he often watches when he enters his room at work.

\footnotetext{
${ }^{1}$ For more information you can look: https://www.jstor.org/stable/pdf/3354931.pdf (25.02.2021)
} 


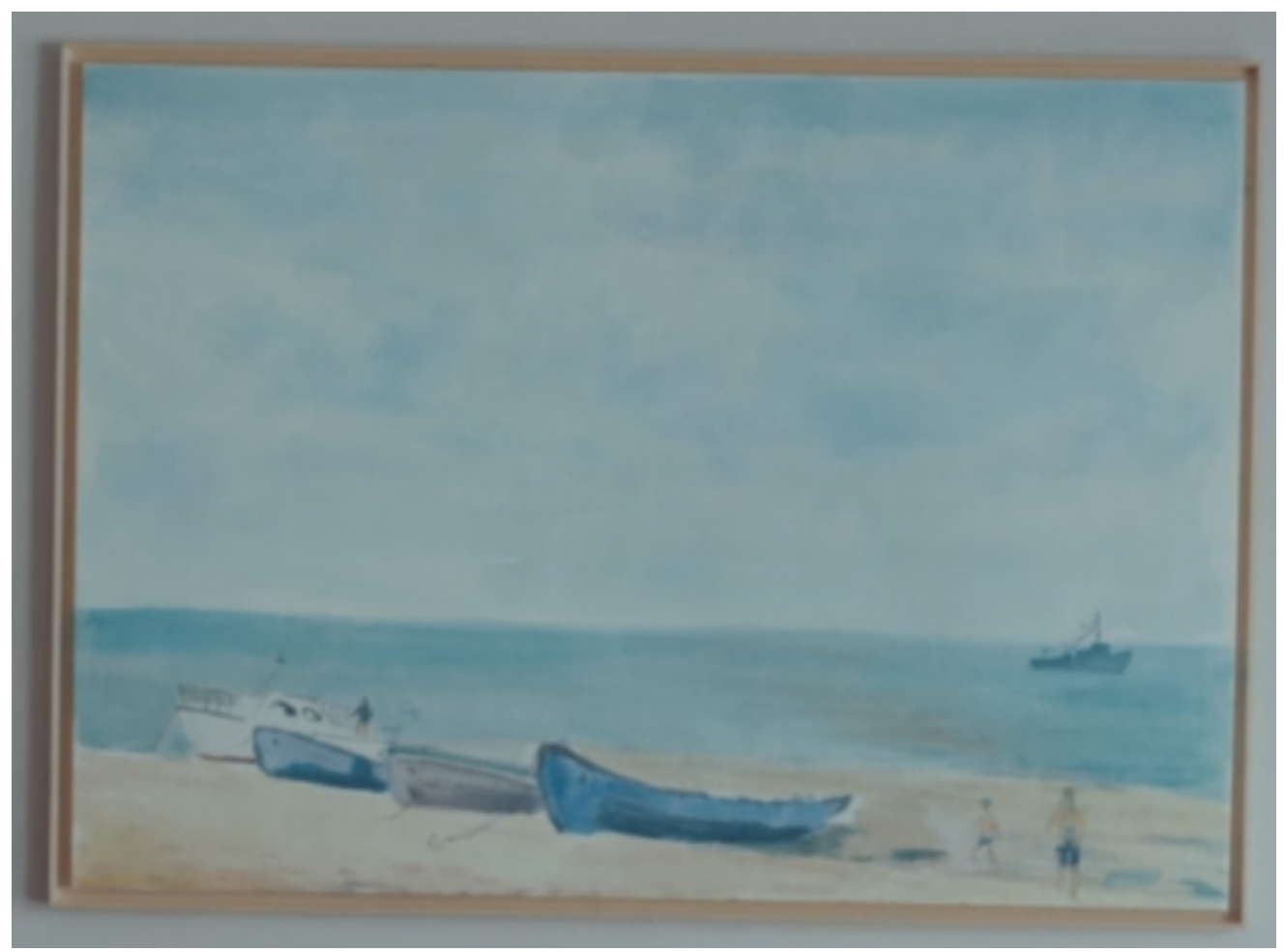

Image 1: First painting at the office

After everyone around learns that his wife was awakening from a coma in a healthy way, he devotes all his attention to his new clients. His new clients are two mourning middleaged brother and sister whose father was killed by a thief who entered the house with his yellow bike. His clients want the murder to be clarified and a young boy they think is guilty to go to jail. The hero frequently visits these two sibligs, especially one of them, who is a woman, attracts his attention because she is constantly crying and mourning for her father. The protagonist meets this woman unnecessarily and asks her if she is crying too often, but these questions are irrelevant for his defense in court. He visited the crime scene and was shown to the audience through cameras while he was looking carefully at the crime scene photographs. While all these events were happening, he continued to meet with his friend Nikos, even demanded tear gas from him and asked him to secretly give it to him in the locker cabin. When he got home, he poured this gas into his face and tried to cry, because the tear-jerker movies he watched did not help him cry. He fails to imitate the act of crying, and it is observed that his desire for him increases as he fails. When listening to his clients' story does not give him anything, he sees the remedy in tear gas, even if he tries to open his body to encounters several times, his mind will fail to invoke images of the law since he has not experienced such a feeling before.

Throughout the film, writings appear with music on a black screen intermittently, in this writings people are criticized for crying in movies in a false way, and the writings gradually turn into a lyrical or even a divine mourning story. In the middle of the film, it will be realized that these writings are the inner voice of the main protagonist, and some of them will be understood to be lyrics for a requiem he composed for his wife. He warned his son not to play cheerful songs, and immediately afterwards he singed this requiem that he composed for his wife and informed the audience about these writings that appear on a black screen. However, even while singing this requiem, his facial expression does not change, there is neither sadness nor joy on his face, he is only a performer, but is seen as far from feeling. 
The main character is seen visiting his father's house several times throughout the film. His father is a man holding a whiskey glass all the time, and he is seen listening to his son carelessly in his house with a wonderful sea view. While the hero tells his father about his concerns about his wife, the father is expressionless, he is usually seen looking at the sea view, not his son. The protagonist includes his dog to the stories he tells, perhaps in order to make his experiences more visible to his father, and says that even the dog misses his wife, but nothing he says does not seem to work with his father, who seems to be living in his world. His father constantly offers him a drink in response, and the father and son fill their glasses and sip their drinks without looking at each other. During one visit, he tells his father that his hair has turned gray and that his wife's condition has made him old, and asks him look at his hair. His father looks carefully at his son's hair and states that he has not even a single grey hair, and this is the first time he is seen caring for his son in this film. The main character also talks about this hair graying situation with his client, and when the man says that his hair turns white overnight after his father dies, a momentary expression of jealousy appears on his face, but as his father said, his own hair did not turn white due to his wife's mourning. The character's relationship with his son is also not very different from his relationship with his own father, he rarely talks to his son, he goes to his piano teacher to mention that his son's hands are small and he is worried that he will not be able to play the piano well. Later, they are seen contacting the piano teacher by measuring the length of their hands, i seems that their hands are almost the same size. After this action, when the piano teacher says positive things about his son's talent, he cannot find the painful experience he sought from this contact and tries to prevent his son from playing the piano by cutting the strings of the piano. His son, who is at least as unexpressive as he is, constantly repeats the melody he plays on the piano with the strings cut, it does not bother him if the keys are broken, it seems enough for him to hit the correct notes mathematically. The director will share the audience with the mechanics of the music, not the feeling, through this child.

Throughout the film, the hero has so prepared himself for the death of his wife and the mourning, that he thinks about everything from the requiem he will sing after her death to the funeral clothes. When the tragedy he has been waiting for never happens, he sails with his $\mathrm{dog}$, Cookie, and leaves him in the open sea. He goes to work and changes the painting of calm sea that he looks at every day with a painting of a ship lying on its side in a storm. In this part of the film, as can be understood from the anger in the painting, it is observed that the main hero begins to exhibit completely unusual attitudes.

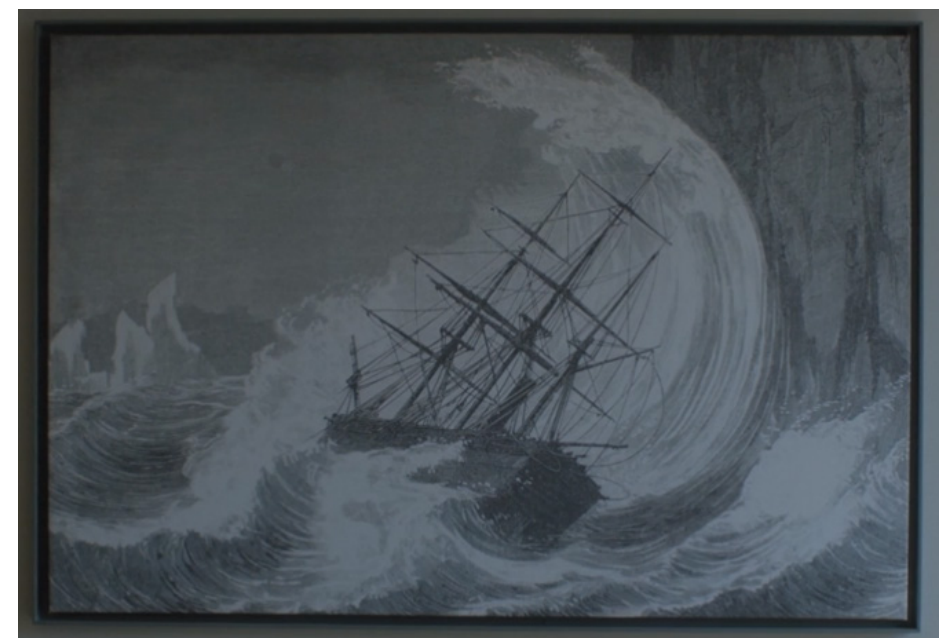

Image 2: Second painting at the office 
After that, he tells his father that the dog is lost in the forest, he goes to the forest one night with his wife and child to search for his dog, but he cannot feel the feelings he wants. In the next scene, the two yellow bicycles he puts in the trunk of his car seem to inform the audience that terrible events are going to come. While he lost his clients' case by making the child not guilty, he killed his father and his wife by imitating the murderer in this case. Tarde always emphasizes that the word imitation is closely related to the word invention. 'Invention is always, by its very nature, an intersection of imitation rays, an original combination of imitations' (Tarde, 1902, p. 565). So the main character is inventing his own emotion by imitating the same murder in the case file. The main character passes over the blood on a yellow bike in both houses, leaving marks just like the murderer in the case. When his son finally comes home, he will not feel sorry for him, and he probably will kill him after closing the door but his son's death is left unclear to the audience. At this point, Tarde introduces the concept of imitation and suggests that sociality develops through imitation. According to Tarde, a distinction has to be made between learning, memory and habit as reflexive imitation (of oneself by oneself) and as mechanisms involving a relationship with others (Djellal \& Gallouj, 2014, p. 19). From the moment the child is born, he will grow by imitating the people around her/him, and even in the most lonely moments, she/he will ensure the continuity of communication and therefore imitation by talking to someone in her/his mind. Starting from their close circles people will have somehow established a relationship with everyone they encounter, and sometimes even movie / novel characters will be involved in this act of imitation, and this partnership will pave the way for sociality. It is universal repetition that explains similarity, whether social, biological or physical. Thus similarities in the social world are the direct or indirect consequences of various expressions of imitation, whether determined by fashion, custom, sympathy, obedience or education, whether deliberate or instinctive, etc. 'Each instance of social similarity has its origins in imitation' (Tarde, 1890 [1993], p. 40). However, the main character chooses to imitate the feelings of the killer because he could not see an impression of emotion from his family. "An individual is, most of all, a passage and sedimentation zone of social flows that are repeated in him (or her) in the form of judgments, memories, wills, and habits" (Tonkonoff, 2013, p. 271). However, this flow will stop because of the main character who does not know how to open himself to emotions, this character, whose past, future and even his name are unclear, seems to have taken his present out of the circle by suspending justice even though he is a lawyer.

In the last sequence of the film, we see the main protagonist crying, as if the director aimed to give the audience a catharsis as if he had given a happy ending. Since the main character cannot open his body to encounters, he has to perform his own encounters through imitations. At this point, the body will be able to envision the emotions it experiences in its mind. Unable to socialize, the character cannot open himself up to encounters, he envisions them in his mind, but this causes him to become more withdrawn and his psychology to become unbalanced. All his speeches about mourning are ignored carelessly, the person who cannot see the sense of pity tries to internalize the mourning of other people, the feeling of pity for them. The perception of Tarde is that this is not a sociality but a spirituality, it will be shaped by the arguments that social events are explained by individuals imitating each other (Balc1, 2014, p. 305). However, the main character, which we saw stretched like a bow throughout the movie, finally found his target by leaping from the bow like an arrow. At the end of this sequence, it is seen that the dog comes out of the sea. While the sea, sun, sand and dog are shown for the last time, the audience will feel that there is still hope despite all this tragedy. The main character, who cannot open his body to encounters, and therefore cannot imagine the feeling of mourning in his mind, eventually creates his own mourning by creating his own encounters. It is unclear what will happen to the main protagonist next, but the film never focuses on the result, it focuses on lack of feelings, it focuses on mourning... 


\section{Conclusion}

Modernity has created a very objective world idea in which emotions are thrown into the background, focused on consumption in the company of liberal economic rules. The capitalist discourse imposes a thought on people to be happy by reaching and consuming the objects they desire. The hero we see in the movie has fulfilled this maxim to the end, but he has a life where even the feeling of happiness is not seen. The main hero is like the ideal person designed by the capitalist order, with his luxurious house furnished in a minimal style, simple and elegant items, stylish suits that never fail to iron, and his office at least as comfortable as his home. He is unhappy in all this luxury and is far from desiring the object, he is after only one emotion, he desires the tragedy which he thinks is missing in his life A parallel story is observed in Krzysztof Kieslowski's Trois Couleurs: Bleu (Üç Renk: Mavi, Krzysztof Kieslowski, 1993) movie. However, in this movie, the main character Julie has everything to mourn, Julie lost her husband and daughter in a traffic accident, her peaciful life was suddenly taken away from her, everyone expects her to mourn, but she cannot mourn properly. Throughout the film, she focuses on running away from a missing composition and erasing everything in her life that reminds her to mourn for her losses. Just like the incomplete requiem in Pity, the composition, the missing piece, which her husband could not complete, is heard in her ears and follows Julie wherever she goes. In the film Pity, the object of mourning does not exist, the main hero takes action to complete this half lament and create the object of mourning that he desires. The end of both films gives the audience what they want, Julie completes the missing composition and mourns correctly and cries at the end of the film, and the main character in the film Pity creates the object of his mourning by killing his whole family and cries by meeting the tragedy that he is looking for. Driven by the ideal main characters (hardworking, rich, middleupper class) determined by the modern world, these two films encounter cold characters who are lack of emotions. It is observed in both characters that there is no desire for objects, one is selling all her possessions and the other is not seen even touching the object, let alone enjoying his valuable assets. Both characters who are so adapted to urban life and capitalist order intend not to tell an ordinary story to the audience, both of them are closed theirselves to encounters. Unable to encounter objects, these bodies limit the mental imagination and experience an emotional blockage. Even if they are not aware of it, they need encounters in order to unleash their blocked emotions. These two films, shot 25 years apart, can be described as the product of the same monolithic mindset. Emotional void experienced as a result of a meta narrative that puts the concept of mind above the concept of body and thus causes the body to lose its importance, not including encounters in all this struggle. As for Spinoza, he also suggests that positive emotions that increase the conatus should be encountered while conveying how important encounters are in society. Positive encounters such as happiness, friendship and love will encourage the body and open it to more encounters, but he will not suggest emotions such as sadness, hatred, anger, because of these feelings will reduce the conatus. Baker, on the other hand, argues that without discriminating emotions, sociality will be established through common affective experiences, otherwise sociality will collapse, and society as we know cannot be more than a crowd of people. The film emphasizes the feeling of loss rather than focusing on positive emotions, desiring to lose something that he hasn't lost, like fear without an object. Judith Butler talks about the importance of loss and says: the loss united us in a loose "we". If we lost, then we had, wanted and loved, we struggled to find the conditions of our desire (Butler, 2005, p. 36). Throughout the film, the main character tries to explain the feeling of loss, even if it is not something that he has lost, because perhaps he will only be able to grasp the importance of life when it is something that can be lost. The value of life can only come to the fore in conditions where loss is considered important. Hence mourning is only an assumption about life that matters... When there is no mourning, there is no life or something other than life is experienced. (Butler, 2009, pp. 21-22). However, it is necessary to end our words by looking at the state of mourning as the most desired emotion from a Spinoza's perspective. "Spinoza will designate two poles on this melodic line of continuous variation and emotion: Joy-Sorrow. 
These will be the basic passions for him: any passion that includes the diminution of my power to act, whatever passion is sorrow, any passion that encompasses an increase in my power to act will be called joy" (Deleuze, 2000, p. 17). So we should seek to desire good feelings, but the main character in the film feels the desire for a negative emotion with a Spinozian perspective. At this point, Spinoza points out that power mostly focuses on the desire of sad feelings and asks: "How is it that people in power need to affect us in a sorrowful way, regardless of the field? Why do they need sad passions?" (Deleuze, 2000, p. 17). According to him, the answer is hidden in the relationship between the priest and the believers, the priest tells them that this world is sad and must obey the rules of religion in order to find happiness, in order to subordinate his subjects, the situation in the modern world is not very different. Modern power directs the people it dictates, not happiness, but negative emotions, but promises that people can be happy if they obey it. "Spinoza was aware of the fact that everything is a game between potentia (power to act) and potestas (sovereign power). While the first is the way of enjoying life, producing and creating pleasures, the second is the situation in which we break away from our power to act and sink into unhappiness, fear and terror" (Baker, 2012, p. 343). However, by condemning the people and individuals to potestas, the Power takes away their power to act and thus gains the power to govern them as they wish. In this case, all nagative feelings like loss or mourning are presented to the attention of people for the promise of a beautiful future, and perhaps the main character of the film pursues negative affects in order to be happy.

In his book From Opinions to Images, Baker mentions that sociality has suffered. Modern society has preferred to isolate everything outside of the mind from life, thus individuals who are disconnected from each other have become floating in sociality. His suggestions for this include reconstructing social types and opinion leaders. In this way, people will find someone to care for again, behaving like them and meet common notions. What he proposes in this context is the sociology of emotions. "Even if the sociology of emotions does not directly focus on social types, the sociology of emotions must be a dual experience: the first takes us towards literature, especially the novel, while the second takes us to the cinema, especially to the type of film we now call "documentary" in a narrow term." (Baker, 2015, p. 45). Apart from all these, according to him, there is also a third experience that the sociology of emotions takes us. "However, a third and more fundamental dimension will of course be Spinoza's extremely deep "theory of emotions". Of course, everything leads us to the idea that images, opinions and thoughts can actually gain meaning in a process of influences and emotions in social life" (Baker, 2015, p. 45). Spinoza's suggestion, based on the concept of affect, seems to prevent people from desperate pursuit of emotions in social life like the main character in the movie Pity, and suspending the rules in order to experience feelings that they cannot imitate. Opening the body to encounters provides significant gains in empathy for the mental process, which is important for rebuilding sociality, and these encounters will lead people to the sociology of emotions. Throughout the film, the main character, who does not have any sensual contact with anyone and who is not seen to feel anything other than the attempts to imitate false mourning, can only feel emotionally saturated in such a field of affections. The Greek Strange Wave emerged in a process that was changed by the economic crisis and that the process of accession to the European Union had a great impact on the society. Throughout the history of cinema, many currents have emerged during such political and social processes. These changes transform the audience and the filmmaker to the extent that the interaction of cinema with life and the forms of being human and socialization can be observedThe main character in the movie Pity fails to open himself up to encounters, his mind and body are torn apart as a result of modern thinking, and the main character is dragged in pursuit of false emotions, not knowing where the shortcoming is. When he finally reaches the emotion, he goes outside the social norms and becomes a legal criminal. While Tarde argues that emotions and all sociality are learned through imitation, Spinoza foresaw the distress that modernity would create much earlier than him, and realized that the Cartesian thought, which separates the mind and the 
body, would shift the emotions to the back of the mind. The modern thought, in which the mind has risen to the top of the hierarchy, devoid of emotions, has pushed emotions and many human things into the background. However, according to Spinoza, the body that is not open to encounters cannot feed the mind, and the life force of the mind that cannot be fed, namely its conatus decreases. In this context, Derrida, based on Spinoza, stated that the separation of body and mind should disappear, and that the ties between the two would come to the fore and would pave the way for sociality. Based on the movie, the very rational life of the main character, his luxurious life and all his wishes, which were met in the liberal economic system, cannot open a space for his feelings. Because human is a being with not only material but also spiritual needs, therefore he desires a feeling of mourning that is not a character object throughout the movie, he tries to create this mourning object with his own hands, the end of the movie ends like this, what will happen to the main hero after this effort is not given to the audience because what the movie wants to convey is the process itself.

\section{Conflict of Interest Statement}

The author of the article declared that there is no conflict of interest.

\section{Kaynakça}

Ahmed, S. (2014) Duyguların Kültürel Politikası, Çev. Sultan Komut, Sel Yayıncılık, İstanbul.

Baker, U. (2012) Kanaatlerden İmajlara, Çev. Harun Abuşoğlu, Birikim Yayınları, İstanbul.

Baker, U. (2015) Beyin Ekran, Der. Ege Berensel, Birikim Yayınları, İstanbul.

Balc1, M. E. (2014). Tarde'1 neden tardettik? Türk sosyolojisine dair soy-kütüksel bir deneme, Sosyoloji Dergisi, 3. Dizi, 29. Say1, 2014/2, s.293-325

Bansidhar, B. (2000) An Examınation Concerning Dualısm In Rene Descartes And Deconstruction Of Jacques Derrıda, School of Language, Literature \& Culture Studies Jawaharlal Nehru University New Delhi, India (Phd Thesis)

Basea, E. (2016) " The 'Greek Crisis' through the Cinematic and Photographic Lens: From 'Weirdness' and Decay to Social Protest and Civic Responsibility." Visual Anthropology Review 32(1): 61- 72.

Butler, J. (2005) Kırılgan Hayat, Çev. Başak Ertür, Metis Yayınları, İstanbul.

Butler, J. (2009) Savaş Tertipleri, Çev. Şeyda Öztürk, YKY Yayınları, İstanbul.

Deleuze, G. (2005) Spinoza Pratik Felsefe, Çev. Ulus Baker, Norgunk Yayınları, İstanbul.

Deleuze, G. (2000) Spinoza Üzerine 11 Ders, Çev. Ulus Baker, Öteki Yayınevi, Ankara.

Derrida, J. (2014) Gramatoloji, Çev. İsmet Birkan, Bilgesu Yayıncılık, İstanbul.

Djellal, F., \& Gallouj, F. (2014). The laws of imitation and invention: Gabriel Tarde and the evolutionary economics of innovation, Retrieved from http://econpapers.repec.org/paper/ halwpaper/halshs-00960607.htm (25.02.2021)

Karmitz M. (Producer), \& Krzysztof, K. (Director). Trois Couleurs: Bleu, France: Mk2 Productions

Klos, P. (2014), Duality of the Sign Deconstructed On the Basis of the Works by Jacques Derrida, Styles Of Communication, Vol. 6, no. 1/2014: 94-101.

Livanou A., Konstantakopoulos C. V., Smieja K., Rzezniczek B. (Producers ), \& Makridis, B. (Director). (2018). Oiktos, Athens: Neda Film.

Moran, Dermot, Introduction to Phenomenology, Rotledge Press, New York and London 2000. 
Nikolaidou, A. "The Performative Aesthetics of the 'Greek New Wave.'" Filmcon Journal of Greek Film Studies 2, 2014, p. 21

Spinoza, B. (2011) Ethica, Çev. Çiğdem Dürüşken, Kabalcı Yayınları, İstanbul.

Tarde, G. (1902) L'invention, moteur de l'évolution sociale, Revue internationale de sociologie, X(7), p. 562-74.

Tarde, G. (1890) Les lois de l'imitation (Paris: Félix Alcan; Paris: Editions Kimé, Paris, 1993).

Tonkonoff, S. (2013) A new social physic: The sociology of Gabriel Tarde and its legacy, Current Sociology Vol. 61, no: 3, p. 267-282. 